\title{
The Management Problems and Suggestions of Intangible Assets in Universities
}

\author{
Weiming Wang \& Yanyan Yu \\ Department of Technology Economy and Management, Xi'an University of Architecture and Technology, \\ Xi'an, 710055, China
}

\begin{abstract}
Colleges and universities are the important base of intangible assets, intangible assets between universities and colleges in quantity and quality are the core competitiveness. By introducing the definition, content and characteristics of intangible assets, the author wants to illustrate the importance and difficulty of university intangible assets management, then discuss on the problems existing in the management process in China, and put forward some corresponding policy suggestions, the author aims to improve the level of university intangible assets management, and ensure that "knowledge value-added" and "assets value-added" dual goal.
\end{abstract}

KEYWORD: Management system; Intangible assets; Value-added; Problem; Account

\section{GENERAL INSTRUCTIONS}

University intangible assets refer to the nonmonetary assets of institutions of higher learning owned, which have no physical form, and the life time for more than a year, and which can continue to play a role in social economic activities for the institutions of higher learning, and provides more stable and more than general benefits in the same industry.[1] Generally university intangible assets include the intellectual property rights, the license of government, human resources, school honor and so on. As the core competitiveness of the important resources of colleges and universities, intangible assets is the important reflections of the university's comprehensive strength. Due to the particularity of funding sources in colleges and universities, and the features of not substantive, monopoly, high efficiency, uncertainty of intangible assets, the management is a relatively weak link.

Following the socialist market economic system gradually established, and facing the science and technology resource reconfiguration, and the development of the technology market, and the system reform of property right, and the protection of intellectual property rights, and the fusion of international and domestic market,[2] as well as the cost of high and new technology commercialization, industrialization and internationalization, and in order to realize "knowledge value-added" and "assets value-added" dual goal, the management of intangible assets in China also wants to internationalization, the author analysis problems of the present stage in the process of the intangible assets management in our country, and puts forward relevant policy suggestions on these bases.

\section{THE MAIN PROBLEMS EXISTING IN UNIVERSITY INTANGIBLE ASSETS MANAGEMENT}

\subsection{University intangible assets range boundaries is not clear.}

Management consciousness does not reach the designated position. At present, the definition and standards of intangible assets in universities to relevant state administrative departments and academic circles have extensive controversy, which leads to the relevant management systems, rules and hard to be clear and perfect. the managers of intangible assets management in universities are hard to do it according to the established standards, which can easily lead to the contradictions between the managers and users of intangible assets.[3] Moreover, the managers of intangible assets in universities pay attention to tangible assets than intangible, pay attention to papers than patents. Some universities still look down on "operation"; and look down on "benefit" and "intangible assets", which believe that the characteristic of intangible assets is "nothing", namely invisible; which intrude into "benefit". Some teachers even transfer on-duty inventions in universities to seek petty profit from 
them without permission.

\subsection{The erosion of university intangible assets is serious.}

Since China's reform and opening up, along with the development of market economy, the cooperation between colleges and enterprises are continuously reinforce, mobility of talented personal is becoming more and more frequent. The loss of intangible assets is often happened in this process, which inevitably brings to the big losses of universities, and these losses once form, which are hard to rebuild or restore.

\subsection{The phenomenon of abuse of intangible assets in institutions of higher education is serious.}

The university's reputation is reflected by the past records, academic level, the geographical location, visibility, the internal environment, teachers, students' quality and management level. So the university's reputation is the overall image of a comprehensive effect. Reputation is largely affected by objective and accident factors, which is difficult to measure using a more accurate figure in a period of time. And once after being used, the damage is invisible, which cannot be measured through evaluation.[4] Because management of intangible assets in colleges and universities is imperfect causing the severious abuse of university intangible assets.

\subsection{The management regulation of university} intangible assets is lag behind, and the system is not sound.

Institutions of higher learning do a lot of work in accordance with the provisions to establish and improve the management system, gaining big result. But management regulations are rarely formed into standards for special intangible assets. In particular, along with the increasing extension of university financial management activities, the business of the intangible assets is increasingly frequent. But the corresponding system lags behind, resulting some of accounting, which should be listed as an intangible asset spending, are capitalized timely; In the process of its management transformation, the amortization expenses of intangible assets are rarely appear. Management system is difficult to be in line with reality.

\subsection{The management of intangible assets of colleges and universities should to improve.}

At present, the operational human capital and increment are insufficient, the operators are the key factor restricting the performance of university intangible assets management. The operation and management of intangible assets are done mostly by teachers, or teachers transferred from teaching jobs. The intangible assets management in colleges and universities is lack of professionals with the background of grasping operation, management and law.[5]

\subsection{The accounting of intangible assets is not standard.}

Because the scope, measurement, and dominant role of intangible assets in the financial management in colleges and universities are insufficiently understood, there are some problems in the process of accounting. For example, spending on the expanding land of the requisition scale should be as capital expenditure in the process of the development of colleges and universities, not be simply classified as business spending; moreover, in the process of merging, the assets of merging into colleges and universities should be evaluated, the value-added part of which in addition to tangible assets, should be used as business reputation, etc.

\subsection{Lack of duties and supporting mechanism of talent flow.}

In recent years, many of colleges and universities do not hesitate to introduce talents on generous terms, which promotes the university teaching staff construction, scientific research, the development of the education teaching achievement and prosperity, and has played a positive role in promoting for the talents' own development.[6] However, university did not establish the related mechanism to restrict the flow of talents, which will definitely affect the brain drain and the reputation and strength of universities, resulting in the loss and depreciation of intangible assets.

\subsection{The evaluations of intangible assets don't have legislation to depend on.}

2.9 Lack of protection of intangible assets, shortage of the translation power, the loss of translation income, and the results lay aside.

\section{MEASURES AND SUGGESTIONS OF INTANGIBLE ASSETS MANAGEMENT IN UNIVERSITIES}

\subsection{Internal should register for the existing intangible assets in colleges and universities.}

Set up intangible assets collection catalog at school, which can provide detailed basis for the check of university intangible assets. The intangible assets are 
to be done uniformly and be systematically managed, and glistered and put on record query statistics.

\subsection{Establish special intangible asset management system in universities.}

University intangible assets must be unified under centralized management according to their own situations and the state's relevant laws and regulations, formulating perfect intangible assets control regulations, and making the job of intangible assets of the school having rules to follow. University intangible assets management system should not only be fully and accurately covers each link of university intangible assets management, but also have to be operable.

\subsection{Design intangible assets information management system in universities.}

Colleges and universities can take advantage of the long-term accumulation of experience and practical theory of intangible assets, developing the modern intangible assets information management system suitable for their own schools. The system should fully reflect the current status of university intangible assets, effectively monitor the development and utilization of intangible assets, which can provide data support for having better management of intangible assets of colleges and universities.[7]

\subsection{Put "intangible assets" to "tangible" through the achievements transformation.}

There are two ways to colleges and universities joining the operation of enterprises to make appropriate "profits". The first kind is they can directly put the research of technological achievements or patents into shares of enterprises, and the enterprise transfers into real products into the market again. So the enterprise can enjoy a profit obtained by the products together with the universities. The second is they can make use of the scientific research funds in colleges and universities by hands doing independently research projects. Then sell the scientific research to related enterprises by the way of "technology transfer", directly acquiring profits. And in which colleges and universities will not responsible for the risk of the product marketing.

\subsection{Strengthen the development and utilization of intangible assets in universities.}

At the huge backdrop of the financial stress in college, protecting intangible assets from another perspective means the problems of maintaining and adding, developing and utilizing of intangible assets value. Universities should practice "internal strength", which strengthens the teaching quality and research level, sets up and maintains a good image, enhances the school's popularity, strengthens the cooperation with local governments and enterprises, makes full use of our advantages in resources, puts the research efforts of our technology into social productivity, make due contributions to economic development for the local education.[3]

\subsection{Set up a scientific accounting method and accounting system of intangible assets.}

Establishing a scientific and reasonable accounting method and accounting system of intangible assets is one of the important measures and guarantees of intangible assets management and value realization. Colleges and universities should build a evaluation system of intangible assets as soon as possible, and establish the evaluation index system, and standardize the evaluation standard and methods of intangible assets. Nowadays, the most simple way is to hire consultants, which have corresponding qualification of appraisal institution, to evaluate university intangible assets.

\subsection{Cultivate professional management talents in universities and colleges.}

Universities and colleges have made the management system of intangible assets, still need a high quality of talent team to better manage, develop, and make good use of university intangible assets. Personnel engaging in the work of the intangible asset management should be both have certain professional knowledge and have the legal knowledge of mixed, practical and innovative talents. But this kind of talents is the most indispensable for the general colleges and universities. With the increasing awareness of protection of intangible assets in colleges and universities, intangible assets management in universities and colleges can use agent management system and hire high-quality talent from the outside.

\subsection{Strengthen the legal protection of intangible assets.}

The normal operation of the market economy depends on a sound legal system as guarantees to strengthen the management of intangible assets in institutions of higher education, which is inseparable from the rigorous and scientific laws and regulations. Our government should establish and perfect the legal system of intangible assets in our 
country as soon as possible to adapt to the development of market economy and improve the level of the intangible assets management in colleges and universities.

\subsection{Establish an effective transformation mechanism of intangible assets.}

Colleges and universities should establish and perfect the system of intangible assets management under the guidance of national policy, take the incentive policies, improve the enthusiasm of teachers in colleges and universities and scientific research personnel and attach great importance to the intangible assets into use in order to establish effective operating mechanism of the intangible assets. First of all, attach great importance to the scientific research achievements into use. Secondly, pay attention to the development and utilization of school to other intangible assets. Finally, attach importance to the operating performance evaluation of university intangible assets. The intangible assets can be converted into one of the important index to use as a college teacher evaluation and assessment indexes, and motivate teachers to take the market as the guidance, and promote the effective transformation of intangible assets.

\section{CONCLUSIONS}

In the new development period, assets management in colleges and universities should also keep pace with the times. With the advent of the era of knowledge economy, intangible assets have become the important component of state-owned assets in institutions of higher education, which have huge potential value, and which also become the basis of the survival and development basis of colleges and universities. Therefore, universities not only attaches importance to the management of tangible assets, but also enhance the consciousness of intangible assets management, and establish and perfect the system of intangible assets management, and strengthen the management of each link of intangible assets to realize the value of intangible assets, and gradually form a harmonious and unified system of intangible assets management.[1] Universities and colleges should always adhere to the the overall thought of "unified cognition, understanding financial of school, overall design, overall coordination, gradual advance" in the management process, which make the management of intangible assets in colleges and universities advancing with the times in order to achieve the dual goal of "knowledge value-added" and "assets valuemaintained and added", making intangible assets better service to the purpose of higher learning education to become a useful person in institutions.

\section{REFERENCES}

[1] Wang Zhengrong, University intangible assets management. Chinese master thesis of Shaanxi Normal University, 2009.

[2] Shi Hong \& Pan Boping, Must strengthen the university intangible assets management and administration. Chinese Journal of Economic Research Guide,1(147), pp.95-96, Jan 2012.

[3] Hao Wei. The thoughts of strengthening the management of intangible assets in institutions of higher education. Chinese Journal of Science \& technology information, 29(2), pp.186, 2009.

[4] Zhou Haiquan \& Xu Xiaomei, The analyses of problems of the intangible assets management. Chinese Journal of The border economy and culture,8(92), pp.157-158, Aug 2011.

[5] Liao Jingming, Yan Mingming \& Huang Yanling, Research on the Operation Strategies of Intangible Assets in Colleges. Chinese Journal of Value Engineering, pp.121, 2010.

[6] Chen Ya, The refinement strategies of intangible assets management. Chinese Journal of Chengdu University (Social Science Edition),5, pp.119-121, May 2012.

[7] Liang Hong, The thinkings of several problems of local university intangible assets management. Chinese Journal of Changchun Normal College (Humanities and Social Science),31(7), pp.83-84, Jul 2012. 